\title{
Pengaruh Likuiditas, Manajemen Aset, Perputaran Kas Dan Struktur Modal Terhadap Kinerja Keuangan pada Perusahaan Manufaktur Yang Terdaftar di Bursa Efek Indonesia
}

\author{
Bayu Wulandari \\ Universitas Prima Indonesia \\ bayuwulandari@unprimdn.ac.id \\ Nici Tasya Edeline Hasibuan \\ Universitas Prima Indonesia \\ nicitasya@gmail.com
}

\author{
Nico Geraldo Sianturi \\ Universitas Prima Indonesia \\ nicogsianturi@gmail.com \\ Imelda Tri Ananta Ginting \\ Universitas Prima Indonesia \\ imeldatrianantaginting@gmail.com
}

\author{
Ardono Simanullang \\ Universitas Prima Indonesia \\ ardonodairi@gmail.com
}

\begin{abstract}
Abstrak
Penelitian ini bertujuan untuk menguji pengaruh likuiditas, manajemen aset, perputaran kas dan struktur modal terhadap kinerja keuangan pada perusahaan manufaktur yang terdaftar di Bursa Efek Indonesia. Penelitian dilakukan dengan pendekatan penelitian kuantitatif. Jenis penelitiannya adalah penelitian deskriptif. Populasi dalam penelitian sebanyak 144 perusahaan dan jumlah sampel sebanyak 77 perusahaan manufaktur yang terdaftar di Bursa Efek Indonesia 2016-2018. Adapun variabel yang berkaitan dengan penelitian ini adalah likuiditas (current ratio), manajemen aset (total asset turnover), perputaran kas (cash turnover), struktur modal (debt to equity ratio) dan kinerja keuangan (Return On Asset). Metode penelitian yang digunakan adalah metode uji asumsi klasik dan analisis regresi linear berganda. Hasil penelitian menunjukkan bahwa secara parsial Likuiditas (Current Ratio) berpengaruh signifikan terhadap Kinerja Keuangan (Return On Asset), Manajemen Aset (Total Asset Turnover) berpengaruh signifikan terhadap Kinerja Keuangan (Return on Asset), PerputaranKas (debt to equity ratio) tidak berpengaruh signifikan terhadap Kinerja Keuangan (Return On Asset), dan Struktur Modal tidak berpengaruh signifikan terhadap Kinerja Keuangan (Return On Asset). Secara simultan Likuiditas (Current Ratio), Manajemen Aset (Total Asset Turnover), Perputaran Kas (Cash Turnover) dan Struktur Modal (Debt to Equity Ratio) berpengaruh signifikan terhadap Kinerja Keuangan (Return On Asset) perusahaan yang terdaftar di Bursa Efek Indonesia.
\end{abstract}

Kata Kunci: Likuiditas (Current Ratio), Manajemen Aset (Total Asset Turnover), Perputaran Kas (Cash Turnover), Struktur Modal (Debt to Equity Ratio), Kinerja Keuangan (Return On Asset). 


\section{Pendahuluan}

\section{I.1 Latar Belakang}

Perkembangan ekonomi setiap perusahaan di era globalisasi saat ini sangatlah dinamis. Dimana masingmasing perusahaan memiliki tujuan utama yang sama. Yakni memperoleh laba atau keuntungan. Dan untuk mempertahankan laba tersebut, dibutuhkan pemeriksaan terhadap kesehatan keuangannya. Adapun cara untuk melihat kesehatan keuangan tersebut yakni dilihat dari rasio keuangannya. Dimana pada prakteknya rasio keuangan ada lima yaitu Rasio Likuiditas, Rasio Solvabilitas, Rasio Aktivitas, Rasio Nilai Pasar, dan Rasio Profitabilitas.
Maka dari kelima rasio keuangan tersebut peneliti menggunakan rasio likuiditas untuk mengukur kemampuan perusahaan dalam mengatasi utang jangka pendeknya yakni analisis yang digunakan adalah Current Ratio dan perputaran kas. Rasio solvabilitas digunakan untuk mengetahui sejauh mana aktiva perusahaan dibiayai dengan utang, yang diukur dengan menggunakan Debt To Equity Ratio dan rasio aktivitas yang digunakan adalah TATO (Total Assets Turnover). Sehingga peneliti dapat menggunakkan ke empat rasio tersebut untuk mengukur seberapa besar pengaruhnya terhadap kinerja keuangan yaitu ROA (Return On Assets) khususnya pada perusahaan manufaktur yang terdaftar di Bursa Efek Indonesia.

Tabel 1.1 : Fenomena Penelitian (Dinyatakan dalam Rupiah)

\begin{tabular}{|c|c|r|r|r|r|r|}
\hline \multirow{2}{*}{$\begin{array}{c}\text { KODE } \\
\text { EMITEN }\end{array}$} & TAHUN & \multicolumn{1}{|c|}{ ASET LANCAR } & TOTAL ASET & PENJUALAN & TOTAL EKUITAS & $\begin{array}{c}\text { LABA BERSIH } \\
\text { SETELAH PAJAK }\end{array}$ \\
\hline \multirow{3}{*}{ AKPI } & 2016 & 870.146 .141 .000 & 2.615 .909 .190 .000 & $\mathbf{2 . 0 4 7 . 2 1 8 . 6 3 9 . 0 0 0}$ & 1.120 .035 .169 .000 & $\mathbf{5 2 . 3 9 3 . 8 5 7 . 0 0 0}$ \\
\cline { 2 - 7 } & 2017 & $\mathbf{1 . 0 0 3 . 0 3 0 . 4 2 8 . 0 0 0}$ & 2.745 .325 .833 .000 & $\mathbf{2 . 0 6 4 . 8 5 7 . 6 4 3 . 0 0 0}$ & 1.126 .612 .491 .000 & $\mathbf{1 3 . 3 3 3 . 9 7 0 . 0 0 0}$ \\
\cline { 2 - 7 } & 2018 & $\mathbf{1 . 2 3 3 . 7 1 8 . 0 9 0 . 0 0 0}$ & 3.070 .410 .492 .000 & 2.387 .420 .036 .000 & 1.233 .833 .753 .000 & $\mathbf{6 4 . 2 2 6 . 2 7 1 . 0 0 0}$ \\
\hline \multirow{3}{*}{ TALF } & 2016 & 325.494 .162 .443 & $\mathbf{8 8 1 . 6 7 3 . 0 2 1 . 9 5 9}$ & 569.419 .992 .907 & 751.895 .484 .830 & $\mathbf{3 0 . 1 3 7 . 7 0 7 . 3 2 4}$ \\
\cline { 2 - 7 } & 2017 & 351.255 .636 .607 & $\mathbf{9 2 1 . 2 4 0 . 9 8 8 . 5 1 7}$ & 646.087 .885 .410 & $\mathbf{7 6 6 . 1 6 4 . 8 3 1 . 7 8 3}$ & $\mathbf{2 1 . 4 6 5 . 8 3 6 . 7 8 4}$ \\
\cline { 2 - 7 } & 2018 & 405.988 .723 .901 & 984.597 .771 .989 & 741.055 .147 .778 & $\mathbf{8 0 8 . 3 7 8 . 9 8 6 . 8 0 6}$ & $\mathbf{4 3 . 9 7 6 . 7 3 4 . 0 0 0}$ \\
\hline
\end{tabular}

Berdasarkan tabel 1.1 diatas menunjukkan 2 contoh perusahaan manufaktur maka fenomena yang terjadi pada perusahaan PT. Argha Karya Prima Ind. (AKPI) Tbk dari tahun 2017 ke tahun 2018 mengalami kenaikan aset lancar sebesar Rp. 230.687.662.000. Sedangkan laba bersih setelah pajak mengalami kenaikan dari Rp. 13.333.970.000 pada tahun 2017 menjadi Rp. 64.226.271.000 di tahun 2018 . Perusahaan ini juga mengalami kenaikan penjualan pada tahun $2016 \mathrm{ke}$ tahun 2017 sebesar Rp. 17.639.004.000, sedangkan laba bersih setelah pajak mengalami penurunandari Rp. 52.393.857.000 pada tahun 2016 menjadi Rp. 13.333.970.000 di tahun 2017. 
Pada perusahaan PT. Tunas Alfin (TALF) Tbk dari tahun 2016 ke tahun 2017 mengalami kenaikan total aset sebesar Rp. 39.567.966.558. Sedangkan laba bersih setelah pajak mengalami penurunan dari Rp. 30.137.707.324 pada tahun 2016 menjadi Rp. 21.465.836.784 di tahun 2017. Perusahaan ini juga mengalami kenaikan total ekuitas pada tahun 2017 ke tahun 2018 sebesar Rp. 42.214.155.023, sedangkan laba bersih setelah pajak mengalami kenaikan dari Rp. 21.465.836.784 pada tahun 2017 menjadi Rp. 43.976.734.000 di tahun 2018.

Berdasarkan latar belakang diatas, peneliti tertarik untuk mengambil judul "Pengaruh Likuiditas, Manajemen Aset, Perputaran Kas dan Struktur Modal terhadap Kinerja Keuangan pada Perusahaan Manufaktur yang terdaftar di Bursa Efek Indonesia”.

\section{Tinjauan Pustaka}

\subsection{Kajian Pustaka}

\section{I.2.1.1 Likuiditas}

Menurut (Fahmi, 2017), rasio likuiditas (liquidity ratio) adalah potensi suatu perusahaan memenuhi kewajiban jangka pendeknya secara tepat waktu.

Menurut (Hery, 2015), berpendapat bahwa rasio untuk mengukur likuiditas adalah rasio lancar (current ratio). Current ratio digunakan untuk mengukur potensi perusahaan dalam memenuhi kewajiban (utang) jangka pendeknya yang segera jatuh tempo dengan menggunakan total aset lancar. Rumus indikator yang digunakan untuk mencari rasio lancar adalah sebagai berikut:

$$
\text { Current Ratio }=\frac{\text { Aset Lancar }}{\text { Kewajiban Lancar }}
$$

\subsection{Manajemen Aset}

Manajemen aset adalah proses terstruktur meratakan, pengoperasian, pemeliharaan, upgrade, dan membuang aset biaya efektif. Istilah ini paling sering digunakan dalam dunia keuangan untuk menggambarkan obyek dan perusahaan yang mengelola investasi atas nama orang lain.

Menurut (Brigham \& Houston, 2010), berpendapat bahwa rasio untuk mengukur manajemen aset adalah rasio perputaran total aset (total assets turnover ratio). Total assets turnover ratio merupakan rasio yang digunakan untuk mengukur perputaran seluruh aset perusahaan dan dihitung dengan membagi penjualan dengan total aset. Rumus indikator yang digunakan untuk mencari rasio perputaran total aset adalah sebagai berikut:

$$
\text { Total Assets Turnover }=\frac{\text { Penjualan }}{\text { Total Aset }}
$$

\subsection{Perputaran Kas}

Menurut (Nuriyani \& Zannati, 2017), perputaran kas merupakan periode berputarnya kas dimulai pada saat dimana kas itu diinvestasikan dalam modal kerja yang tingkat likuiditasnya paling tinggi agar tercapainya volume penjualan yang tinggi pula. Menurut (Nurafika \& Almadany, 2018), rumus indikator yang 
digunakan untuk mencari rasio perputaran kas adalah sebagai berikut:

$$
\begin{gathered}
\text { Cash Turnover }=\frac{\text { Penjualan }}{\text { Rata }- \text { Rata Kas }} \\
\text { Rata }- \text { Rata Kas }=\frac{\text { Kas Awal }+ \text { Kas Akhir }}{2}
\end{gathered}
$$

\subsection{Struktur Modal}

Menurut (Fahmi, 2017), Struktur Modal merupakan gambaran dari bentuk skala keuangan perusahaan yaitu antara modal yang dimiliki yang bersumber dari utang jangka panjang (long-term liabilities) dan modal sendiri (shareholders' equity) yang menjadi sumber pembiayaan suatu perusahaan.

Menurut (Hery, 2015), berpendapat bahwa rasio untuk mengukur struktur modal adalah Debt to Equity Ratio. Debt to Equity Ratio merupakan rasio yang digunakan untuk mengukur besarnya proporsi utang terhadap modal. Rumus indikator yang digunakan untuk mencari Debt to Equity Ratio adalah sebagai berikut:

$$
\text { Debt to Equity Ratio }=\frac{\text { Total Utang }}{\text { Total Modal }}
$$

\subsection{Kinerja Keuangan}

Menurut (Fahmi, 2017), kinerja keuangan adalah suatu penjabaran dan penelitian yang dilakukan untuk melihat sebatas mana suatu perusahaan telah melaksanakan dengan menggunakan aturan - aturan pelaksanaan keuangan secara baik dan tepat.

Menurut (Hery, 2017), berpendapat bahwa rasio untuk mengukur kinerja keuangan adalah Return on Assets. Return on Assets merupakan rasio yang menunjukkan hasil (return) atas penggunaan aset perusahaan dalam menciptakan laba bersih. Menurut (Nurafika \& Almadany, 2018), rumus indikator yang digunakan untuk mencari return on asset adalah sebagai berikut:

Return On Asset $=\frac{\text { Laba Bersih Setelah Pajak }}{\text { Total Aktiva }} \times 100 \%$

\subsection{Kerangka Pemikiran}

2.6.1. Pengaruh Likuiditas Terhadap Kinerja Keuangan

Rasio yang digunakan dalam likuiditas adalah Current Ratio. Menurut (Subramanyam \& Wild, 2014), rasio lancar (Current Ratio) menunjukkan kemampuannya untuk memenuhi kewajiban lancar. Jika semakin tinggi jumlah (kelipatan) aset lancar terhadap kewajiban lancar maka semakin besar keyakinan bahwa kewajiban lancar tersebut akan dibayar, maka mempengaruhi kinerja keuangan secara dinamis.

\subsubsection{Pengaruh Manajemen Aset} Terhadap Kinerja Keuangan

Rasio yang digunakan dalam manajemen aset adalah rasio perputaran total aset. Menurut (Hery, 2017), perputaran total aset (total assets turnover) menunjukkan bagaimana keefektifan total aset yang dimiliki perusahaan dalam menghasilkan penjualan sehingga mampu meningkatkan kinerja keuangan dengan baik. 
2.6.3. Pengaruh Perputaran Kas Terhadap Kinerja Keuangan

Menurut (Widiasmoro, 2017), perputaran kas (cash turnover) menunjukkan kemampuan kas dalam menghasilkan pendapatan, sehingga dapat mempengaruhi kinerja keuangan perusahaan secara keseluruhan.

\subsubsection{Pengaruh Struktur Modal Terhadap Kinerja Keuangan}

Rasio yang digunakan dalam struktur modal adalah Debt to Equity Ratio. Menurut (Lestari \& Dewi, 2016), nilai debt to equity ratio yang rendah menunjukkan kinerja keuangan perusahaan (return on assets) yang baik karena semakin tinggi kemampuan perusahaan untuk membayar kewajibannya.

\subsection{Kerangka Konseptual}

Untuk mengetahui hubungan antara variabel independen (x) dengan variabel dependen $(\mathrm{y})$ yang digunakan dalam penelitian ini dapat dilihat pada gambar 1.1 berikut:

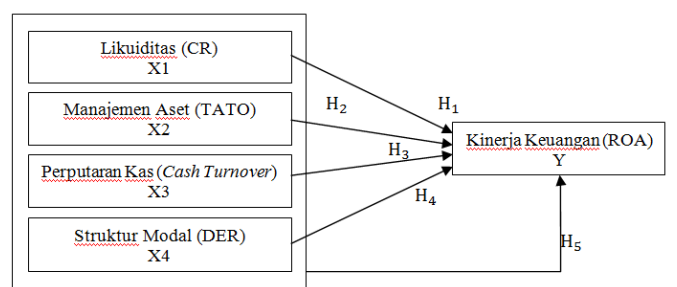

Gambar 1.1. Kerangka Konseptual

\subsection{Hipotesis Penelitian}

Berdasarkan kerangka konseptual hipotesis di atas maka hipotesis yang diajukan dalam penelitian adalah sebagai berikut:
H1: Likuiditas (CR) secara parsial berpengaruh signifikan terhadap kinerja keuangan (ROA) pada perusahaan manufaktur yang terdaftar di Bursa Efek Indonesia.

H2: Manajemen Aset (TATO) secara parsial berpengaruh signifikan terhadap kinerja keuangan (ROA) pada perusahaan manufaktur yang terdaftar di Bursa Efek Indonesia.

H3: Perputaran Kas (Cash Turnover) secara parsial berpengaruh signifikan terhadap kinerja keuangan (ROA) pada perusahaan manufaktur yang terdaftar di Bursa Efek Indonesia.

H4: Struktur Modal (DER) secara parsial berpengaruh signifikan terhadap kinerja keuangan (ROA) pada perusahaan manufaktur yang terdaftar di Bursa Efek Indonesia.

H5: Likuiditas (CR), Manajemen Aset (TATO), Perputaran Kas (Cash Turnover) dan Struktur Modal (DER) secara simultan berpengaruh signifikan terhadap kinerja keuangan (ROA) pada perusahaan manufaktur yang terdaftar di Bursa Efek Indonesia.

\section{Metode Penelitian}

\subsection{Pendekatan Penelitian}

Pada pendekatan penelitian ini, peneliti menggunakan metode penelitian kuantitatif. Menurut (Sugiyono, 2011), penelitian kuantitatif 
dapat didefinisikan sebagai metode penelitian berlandaskan pada filsafat positivisme, digunakan untuk meneliti pada populasi atau sampel tertentu, teknik pengambilan sampel pada umumnya dilakukan secara random, pengumpulan data menggunakan instrumen penelitian, analisis data bersifat kuantitatif/statistik dengan tujuan untuk menguji hipotesis yang telah ditetapkan. Filsafat positivisme memandang fenomena itu dapat diklasifikasikan konkrit, teramati dan terukur.

\subsection{Sifat Penelitian}

Penelitian yang dilakukan bersifat kausal. Menurut (Sugiyono, 2011), hubungan kausal adalah hubungan variabel yang bersifat sebab dan akibat, sehingga dalam penelitian ada variabel independen dan dependen.

\subsection{Identifikasi dan Definisi} Operasional Variabel Penelitian

Menurut (Sugiyono, 2011), variabel penelitian adalah suatu obyek yang berbentuk apa saja yang ditetapkan oleh peneliti untuk dipelajari sehingga diperoleh informasi tentang hal tersebut dan kemudian ditarik kesimpulannya.

Variabel independen yang digunakan dalam penelitian ini adalah kinerja keuangan yang diproksikan dengan Return On Assets (ROA). ROA digunakan untuk mengukur kemampuan perusahaan dalam memperoleh keuntungan. Menurut (Sujarweni, 2014), variabel independen merupakan variabel yang menjadi sebab perubahannya menghasilkan akibat atau timbulnya variabel dependen.

Variabel dependen dalam penelitian ini adalah Likuiditas diproksikan dengan Current Ratio, Manajemen Aset diproksikan dengan Total Assets Turnover Ratio, Perputaran Kas (Cash Turnover), dan Struktur Modal yang diproksikan dengan Debt to Equity Ratio. Menurut (Sujarweni, 2014), variabel dependen merupakan variabel yang akibat atau dipengaruhi oleh variabel bebas.

Definisi operasional variabel yang sudah dijelaskan pada tabel 2.1 adalah sebagai berikut:

\section{Definisi Operasional Variabel}

Tabel 2.1

\begin{tabular}{|c|l|c|c|}
\hline Variabel & \multicolumn{1}{|c|}{ Definisi Variabel } & Indikator Variabel & $\begin{array}{c}\text { Skala } \\
\text { Ukur }\end{array}$ \\
\hline $\begin{array}{c}\text { Likuiditas/ } \\
\begin{array}{c}\text { Current } \\
\text { Ratio } \\
(\mathrm{X} 1)\end{array}\end{array}$ & $\begin{array}{l}\text { Current Ratio merupakan rasio } \\
\text { yang digunakan untuk mengukur } \\
\text { kemampuan perusahaan dalam } \\
\text { memenuhi kewajiban jangka } \\
\text { pendeknya yang segera jatuh } \\
\text { tempo dengan menggunakan } \\
\text { total aset lancar (Hery, 2015) }\end{array}$ & CR $\begin{array}{c}\text { Aset Lancar } \\
\text { Kewajiban Lancar }\end{array}$ & Rasio \\
\hline $\begin{array}{c}\text { Manajemen } \\
\text { Aset/ }\end{array}$ & $\begin{array}{l}\text { Total Assets Turnover Ratio } \\
\text { merupakan rasio yang } \\
\text { digunakan untuk mengukur }\end{array}$ & TATO $=\frac{\text { Penjualan }}{\text { Total Aset }}$ & \\
\hline
\end{tabular}




\begin{tabular}{|c|c|c|c|}
\hline $\begin{array}{l}\text { Total Assets } \\
\text { Turnover } \\
\text { (X2) }\end{array}$ & $\begin{array}{l}\text { perputaran seluruh aset } \\
\text { perusahaan dan dihitung dengan } \\
\text { membagi penjualan dengan total } \\
\text { aset (Brigham \& Houston, 2010) }\end{array}$ & (Brigham \& Houston, 2010) & \\
\hline $\begin{array}{l}\text { Perputaran } \\
\text { Kas/ } \\
\text { Cash } \\
\text { Turnover } \\
\text { (X3) }\end{array}$ & $\begin{array}{l}\text { Cash Turnover merupakan } \\
\text { periode berputarnya kas dimulai } \\
\text { pada saat dimana kas itu } \\
\text { diinvestasikan dalam modal } \\
\text { kerja yang tingkat likuiditasnya } \\
\text { paling tinggi. (Nuriyani \& } \\
\text { Zannati, 2017) }\end{array}$ & $\begin{array}{l}\text { Cash Turnover }=\frac{\text { Penjualan }}{\text { Rata }- \text { Rata Kas }} \\
\text { (Nurafika \& Almadany, 2018) }\end{array}$ & Rasio \\
\hline $\begin{array}{l}\text { Struktur } \\
\text { Modal/ } \\
\text { Debt to } \\
\text { Equtiy Ratio } \\
\text { (X4) }\end{array}$ & $\begin{array}{l}\text { Debt to Equity Ratio merupakan } \\
\text { rasio yang digunakan untuk } \\
\text { mengukur besarnya proporsi } \\
\text { utang terhadap modal (Hery, } \\
2015 \text { ) }\end{array}$ & $\begin{array}{l}\qquad D E R=\frac{\text { Total Utang }}{\text { Total Modal }} \\
\text { (Hery, 2015) }\end{array}$ & Rasio \\
\hline $\begin{array}{l}\text { Kinerja } \\
\text { Keuangan } / R \\
\text { eturn On } \\
\text { Assets } \\
\text { (Y) }\end{array}$ & $\begin{array}{l}\text { Return on Assets merupakan } \\
\text { rasio yang menunjukkan hasil } \\
\text { (return) atas penggunaan aset } \\
\text { perusahaan dalam menciptakan } \\
\text { laba bersih (Hery, 2017) }\end{array}$ & $\begin{array}{l}\text { ROA } \\
=\frac{\text { Laba Bersih Setelah Pajak }}{\text { Total Aktiva }} \times 100 \% \\
\text { (Nurafika \& Almadany, 2018) }\end{array}$ & Rasio \\
\hline
\end{tabular}

\subsection{Populasi dan Sampel}

Menurut (Sugiyono, 2011), populasi adalah wilayah generalisasi yang terdiri atas obyek/subyek yang mempunyai kualitas dan karakteristik tertentu yang ditetapkan oleh peneliti untuk dipelajari dan kemudian ditarik kesimpulannya. Populasi dalam penelitian ini adalah perusahaan manufaktur yang terdaftar di Bursa Efek Indonesia yang berjumlah 144 perusahaan tahun 2016-2018

Menurut (Sugiyono, 2011), sampel adalah bagian dari jumlah dan karakteristik yang dimiliki oleh populasi tersebut. Sampel dalam penelitian ini adalah perusahaan manufaktur pad periode 2016-2018.

Tabel 2.2 : Sampel Penelitian

\begin{tabular}{|c|l|c|}
\hline No & \multicolumn{1}{|c|}{ Kriteria } & Jumlah \\
\hline 1. & $\begin{array}{l}\text { Perusahaan manufaktur } \\
\text { yang terdaftar di Bursa } \\
\text { Efek Indonesia }\end{array}$ & 144 \\
\hline 2. & $\begin{array}{l}\text { Perusahaan manufaktur } \\
\text { yang tidak mempublikasi } \\
\text { kan laporan keuangannya } \\
\text { secara rutin selama } \\
\text { periode 2016-2018 }\end{array}$ & $(32)$ \\
\hline 3. & $\begin{array}{l}\text { Perusahaan manufaktur } \\
\text { yang mengalami } \\
\text { kerugian pada periode } \\
\text { 2016-2018 }\end{array}$ & $(35)$ \\
Jumlah Sampel Penelitian & $\mathbf{7 7}$ \\
\hline Total Sampel (perusahaan 77 \\
x 3 tahun)
\end{tabular}

Sumber: www.idx.co.id(data diolah)

\subsection{Uji Asumsi Klasik}

Penelitian ini menggunakan uji asumsi klasik. Ada empat pengujian dalam uji asumsi klasik yang terdiri dari:

\subsection{Uji Normalitas}


Menurut (Ghozali, 2013), uji normalitas bertujuan untuk menguji apakah dalam model regresi, variabel pengganggu atau residual memiliki distribusi normal. Ada 2 cara untuk mendeteksi apakah residual berdistribusi normal atau tidak yaitu dengan analisis grafik dan uji statistik.

\subsection{Uji Multikolinearitas}

Menurut (Ghozali, 2013), uji multikolinearitas bertujuan untuk menguji apakah model regresi ditemukan adanya korelasi antar variabel bebas (independen). Model regresi yang baik seharusnya tidak terjadi korelasi di antara variabel independen.

\subsection{Uji Heteroskedastisitas}

Menurut (Ghozali, 2013), uji heteroskedastisitas bertujuan menguji apakah dalam model regresi terjadi ketidaksamaan variance dari residual satu pengamatan ke pengamatan yang lain. Jika variance dari residual satu pengamatan ke pengamatan yang lain tetap, maka disebut homoskedastisitas dan jika berbeda disebut heteroskesdatisitas.

\subsection{Uji Autokorelasi}

Menurut (Ghozali, 2013), uji autokorelasi bertujuan mengujji apakah dalam model regresi linear ada korelasi antara kesalahan penggangu pada periode $t$ dengan kesalahan pengganggu pada peride $\mathrm{t}-1$ (sebelumnya).

\subsection{Uji Analisis Regresi Linier Berganda}

Menurut (Sanusi, 2011), regresi linear berganda pada dasarnya merupakan perluasan dari regresi linear sederhana, yaitu menambah jumlah variabel bebas yang sebelumnya hanya satu menjadi dua atau lebih variabel bebas. Pada penelitian ini, ada empat variabel bebas (independen) dan satu variabel terikat (dependen). Dengan demikian, regresi linear berganda dapat dirumuskan dengan:

$$
\mathrm{Y}=\mathrm{a}+\mathrm{b}_{1} \mathrm{X}_{1}+\mathrm{b}_{2} \mathrm{X}_{2}+\mathrm{b}_{3} \mathrm{X}_{3}+\mathrm{b}_{4} \mathrm{X}_{4}+\mathrm{e}
$$

\subsection{Uji t}

Menurut (Ghozali, 2013), uji statistik t pada dasarnya menunjukkan seberapa jauh pengaruh satu variabel penjelas/independen secara individual dalam menerangkan variasi variabel dependen. Hipotesis nol (Ho) yang hendak diuji adalah apakah suatu parameter (bi) sama dengan nol, atau :

$$
\text { Ho : bi }=0
$$

Artinya apakah suatu variabel independen bukan merupakan penjelas yang signifikan terhadap variabel dependen. Hipotesis alternatifnya $(\mathrm{Ha})$ parameter suatu variabel tidak sama dengan nol, atau:

$$
\text { Ha : bi } \neq 0
$$

Artinya, variabel tersebut merupakan penjelas yang signifikan terhadap variabel dependen.

Cara melakukan uji t adalah sebagai berikut:

1. Quick look: bila jumlah degree of freedom (df) adalah 20 atau lebih, dan derajat kepercayaan sebesar $5 \%$, maka Ho yang menyatakan bi $=0$ dapat ditolak bila nilai t lebih dari 2 (dalam nilai absolut). Dengan kata lain kita menerima hipotesis alternatif, yang menyatakan bahwa suatu variabel independen secara individual mempengaruhi variabel dependen. 
2. Membandingkan nilai statistik $\mathrm{t}$ dengan titik kritis menurut tabel. Apabila nilai statistik $\mathrm{t}$ hasil perhitungan lebih tinggi dibandingkan nilai $\mathrm{t}$ tabel, kita menerima hipotesis alternatif yang menyatakan bahwa suatu variabel independen secara individual mempengaruhi variabel dependen.

\subsection{Uji f}

Menurut (Ghozali, 2013), uji f menguji joint hipotesia bahwa b1, b2, b3, dan b4 secara simultan sama dengan nol, atau:

$$
\begin{aligned}
& \text { Ho }: \mathrm{b} 1=\mathrm{b} 2=\ldots \ldots \ldots=\mathrm{bk}=0 \\
& \text { Ha }: \mathrm{b} 1 \neq \mathrm{b} 2 \neq \ldots \ldots . . \neq \mathrm{bk} \neq 0
\end{aligned}
$$

Uji hipotesis seperti ini dinamakan uji signifikansi secara keseluruhan terhadap garis regresi yang diobservasi maupun estimasi, apakah $\mathrm{Y}$ berhubungan linear terhadap $\mathrm{X} 1, \mathrm{X} 2$, $\mathrm{X} 3$ dan $\mathrm{X} 4$. Untuk memenuhi hipotesis ini digunakan statistik $\mathrm{F}$ dengan kriteria pengambilan keputusan sebagai berikut:

1. Quick look: bila nilai $F$ lebih besar daripada 4 maka Ho dapat ditolak pada derajat kepercayaan 5\%. Dengan kata lain kita menerima hipotesis alternatif, yang menyatakan semua variabel independen secara serentak dan signifikan mempengaruhi variabel dependen.

2. Membandingkan nilai $F$ hasil perhitungan dengan nilai $\mathrm{F}$ menurut tabel. Bila nilai $\mathrm{F}$ hitung lebih besar daripada nilai F tabel, maka Ho ditolak dan menerima Ha.

\section{Hasil dan Pembahasan}

\subsection{Uji Asumsi Klasik}

Uji asumsi klasik digunakan sebagai syarat dalam menggunakan model regresi agar hasil regresi yang diperoleh merupakan estimasi yang tepat.

\subsection{Uji Normalitas}

Uji normalitas bertujuan untuk mengetahui apakah dalam model regresi, variabel penggangu atau residual. Uji normalitas digunakan untuk menguji apakah data berdistribusi dengan normal atau tidak yaitu melalui analisis:

Tabel 4.1. Uji Normalitas Kolmogorov Smirnov

One-Sample Kolmogorov-Smirnov Test

\begin{tabular}{llr}
\multicolumn{1}{c}{} & & $\begin{array}{r}\text { Unstandardiz } \\
\text { ed Residual }\end{array}$ \\
\hline $\mathrm{N}$ & Mean & 180 \\
\hline Normal Parameters & Stb & .0000000 \\
\hline Most Extreme Differences & Absolute & .07965311 \\
\cline { 2 - 3 } & Positive & .042 \\
\cline { 2 - 3 } & Negative & .034 \\
\hline Kolmogorov-Smirnov Z & & -.042 \\
\hline Asymp. Sig. (2-tailed) & & .568 \\
\hline \multicolumn{2}{c}{$\begin{array}{l}\text { a. Test distribution is Normal. } \\
\text { b. Calculated from data. }\end{array}$} \\
\hline
\end{tabular}

\subsection{Analisis Grafik}




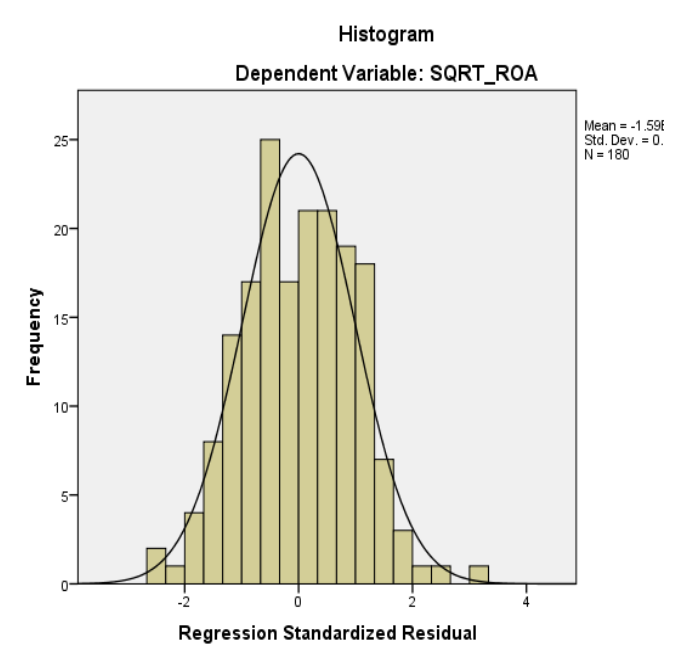

Gambar 4.1 Uji Normalitas Histogram

Berdasarkan tampilan grafik histogram pada gambar 4.1 di atas menunjukkan garis kurva berada di tengah dan tidak dominan ke kanan atau ke kiri sehingga hal ini dapat dikatakan bahwa residual dihasilkan berdistribusi secara normal.

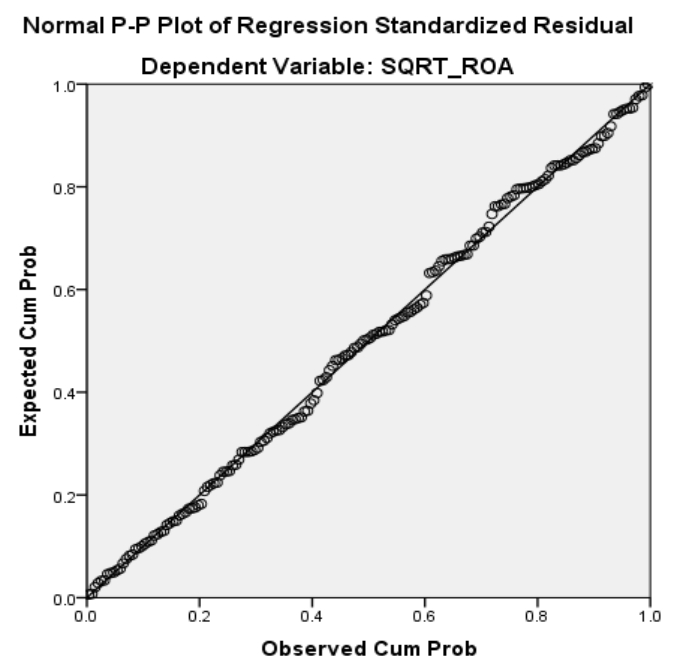

Gambar 4.2. Uji Normalitas Probability Plot
Berdasarkan tampilan grafik normality probability plot pada gambar 3.2 dapat dilihat menunjukkan titik-titik yang ada mengikuti garis diagonal sehingga dapat disimpulkan bahwa data berdistribusi normal.

\section{Analisis Statistik}

Berdasarkan hasil Uji Kolmogorov Smirnov pada tabel $3.1 \mathrm{di}$ atas menunjukkan bahwa variabel CR (X1), TATO (X2), CT (X3), DER (X4)dan ROA (Y) dapat dikatakan berdistribusi normal. Hal ini terlihat dari hasil uji Kolmogorov Smirnov menunjukkan nilai Asymp. Sig. (2-tailed) sebesar $0,903>0,05$.

\subsection{Uji Multikolinearitas}

Uji multikolinearitas bertujuan untuk menguji apakah model regresi ditemukan adanya korelasi antar variabel bebas (independen). Pengujian multikolinearitas dilakukan dengan melihat VIF antar variabel independen.

Tabel 4.2 Uji Multikolinearitas 


\begin{tabular}{|c|c|c|c|c|c|c|c|c|c|c|c|c|}
\hline \multirow[b]{3}{*}{ Model } & \multicolumn{10}{|c|}{ Coefficients $^{a}$} & & \\
\hline & \multicolumn{2}{|c|}{$\begin{array}{c}\text { Unstandardized } \\
\text { Coefficients }\end{array}$} & \multirow{2}{*}{ 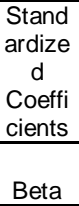 } & \multirow[b]{2}{*}{$t$} & \multirow[b]{2}{*}{ Sig. } & \multicolumn{2}{|c|}{$\begin{array}{c}95,0 \% \\
\text { Confidence } \\
\text { Interval for B }\end{array}$} & \multicolumn{3}{|c|}{ Correlations } & \multicolumn{2}{|c|}{$\begin{array}{l}\text { Collinearity } \\
\text { Statistics }\end{array}$} \\
\hline & B & $\begin{array}{l}\text { Std. } \\
\text { Error }\end{array}$ & & & & $\begin{array}{l}\text { Lower } \\
\text { Bound }\end{array}$ & $\begin{array}{l}\text { Upper } \\
\text { Bound }\end{array}$ & $\begin{array}{l}\begin{array}{l}\text { Zero- } \\
\text { order }\end{array} \\
\end{array}$ & Partial & Part & $\begin{array}{c}\text { Tolera } \\
\text { nce }\end{array}$ & VIF \\
\hline 1 (Constant) & .027 & .053 & & .512 & .609 & -.077 & .131 & & & & & \\
\hline SQRT_CR & .078 & .020 & .344 & 3.797 & .000 & .037 & .118 & .387 & .276 & .254 & .542 & 1.845 \\
\hline SQRT_TATO & .110 & .028 & .271 & 3.941 & .000 & .055 & .165 & .269 & .285 & .263 & .944 & 1.059 \\
\hline SQRT_CT & -.003 & .003 & -.057 & -.747 & .456 & -.010 & .004 & -.165 & -.056 & -.050 & .769 & 1.301 \\
\hline SQRT_DER & -.005 & . 026 & -.016 & -.189 & .850 & -.056 & . 046 & -.228 & -.014 & -.013 & 609 & 1.641 \\
\hline
\end{tabular}

Berdasarkan tabel 4.2 di atas menunjukkan bahwa nilai tolerance variabel CR sebesar 0,542>0,10, nilai tolerance variabel TATO sebesar 0,944 $>0,10$, nilai tolerance variabel CT sebesar $0,769>0,10$, dan nilai tolerance variabel DER sebesar 0,609 > 0,10 . Dan nilai VIF variabel CR 1,845 $<10,00$, nilai VIF variabel TATO 1,059 $<10,00$, nilai VIF variabel CT 1,301 < 10,00 , dan nilai VIF variabel DER $1,641<10,00$. Hal ini dapat menunjukkan bahwa nilai tolerance > dari 0,10 dan nilai VIF < dari 10,00, maka dari hasil tersebut tidak terjadi multikolinearitas dan dapat disimpulkan tidak terjadi korelasi antar variabel independen.

\subsection{Uji Heteroskedastisitas}

Uji regresi dapat dikatakan baik jika tidak terjadi masalah heteroskedastisitas, dalam penelitian ini peneliti mengambil cara dengan menggunakan diagram chart (scatterplot). Dengan dasar pemikiran: 1). Jika ada pola tertentu seperti titiktitik yang membentuk suatu pola tertentu yang teratur (bergelombang, melebar, kemudian menyempit) maka dapat dikatakan terjadi masalah heteroskedastisitas. 2). Jika tidak ada pola yang jelas, serta titik-titik menyebar di atas dan di bawah maka tidak terjadi masalah heteroskedastisitas.

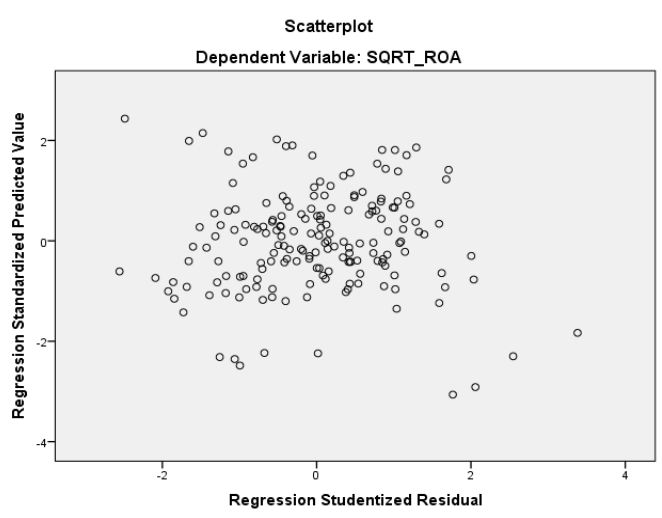

Gambar 4.3. Uji Heteroskedastisitas Scatterplot

Berdasarkan tampilan pada gambar 3.3 di atas dapat dilihat bahwa titik-titik yang ada menyebar secara acak ke atas maupun ke bawah. Dengan demikian dapat disimpulkan bahwa tidak terjadi masalah heteroskedastisitas.

\subsection{Uji Autokorelasi}

Uji autokorelasi bertujuan menguji apakah dalam model regresi linear ada korelasi antara kesalahan penggangu pada periode $t$ dengan kesalahan pengganggu pada peride $\mathrm{t}-1$ (sebelumnya). Dalam penelitian ini test 
yang digunakan adalah Model Summary, dimana jika $\mathrm{d}<\mathrm{dl}$ atau $\mathrm{d}>$ 4-dl maka terdapat autokorelasi, kemudian jika du $<\mathrm{d}<4$-du maka tidak terdapat autokorelasi dan jika dl $<\mathrm{d}<$ du atau 4-du $<$ d $<4$-dl maka tidak ada kesimpulan. Dengan d adalah nilai dari Durbin Watson yang terdapat dalam tabel Model Summary, serta nilai dl dan $\mathrm{du}$ diperoleh dengan cara melihat jumlah sampel (n) dan jumlah variabel independen $(\mathrm{k})$ pada tabel Durbin Watson (DW) sesuai dengan data yang berkaitan.

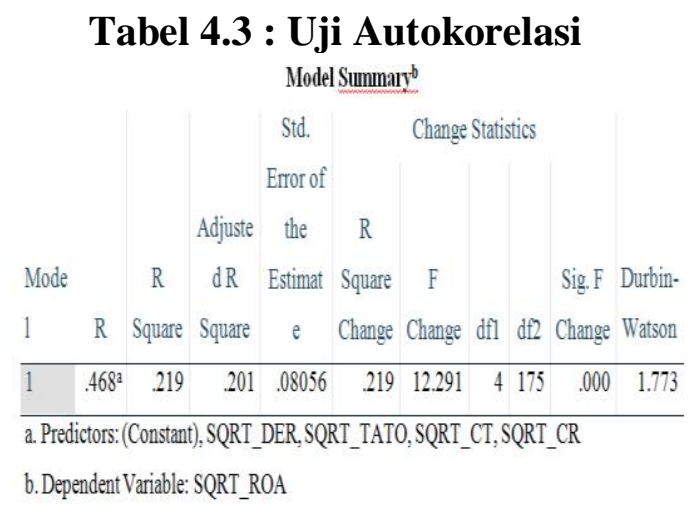

Tabel 3.4

Uji t

Coefficients $^{a}$

\begin{tabular}{|c|c|c|c|c|c|c|c|c|c|c|c|c|}
\hline \multirow[b]{3}{*}{ Model } & \multicolumn{10}{|c|}{ Coefficients $^{a}$} & & \\
\hline & \multicolumn{2}{|c|}{$\begin{array}{l}\text { Unstandardized } \\
\text { Coefficients }\end{array}$} & $\begin{array}{c}\text { Stand } \\
\text { ardize } \\
d \\
\text { Coeffi } \\
\text { cients }\end{array}$ & \multirow[b]{2}{*}{$\mathrm{t}$} & \multirow[b]{2}{*}{ Sig. } & \multicolumn{2}{|c|}{$\begin{array}{c}95,0 \% \\
\text { Confidence } \\
\text { Interval for B }\end{array}$} & \multicolumn{3}{|c|}{ Correlations } & \multicolumn{2}{|c|}{$\begin{array}{l}\text { Collinearity } \\
\text { Statistics }\end{array}$} \\
\hline & B & $\begin{array}{l}\text { Std. } \\
\text { Error }\end{array}$ & Beta & & & $\begin{array}{l}\text { Lower } \\
\text { Bound }\end{array}$ & $\begin{array}{l}\text { Upper } \\
\text { Bound }\end{array}$ & $\begin{array}{l}\text { Zero- } \\
\text { order }\end{array}$ & Partial & Part & $\begin{array}{c}\text { Tolera } \\
\text { nce }\end{array}$ & VIF \\
\hline 1 (Constant) & .027 & .053 & & .512 & .609 & -.077 & .131 & & & & & \\
\hline SQRT_CR & .078 & .020 & .344 & 3.797 & .000 & .037 & .118 & .387 & .276 & .254 & .542 & 1.845 \\
\hline SQRT_TATO & .110 & .028 & .271 & 3.941 & .000 & .055 & .165 & .269 & .285 & .263 & .944 & 1.059 \\
\hline SQRT_CT & -.003 & .003 & -.057 & -.747 & .456 & -.010 & .004 & -.165 & -.056 & -.050 & .769 & 1.301 \\
\hline SQRT_DER & -.005 & .026 & -.016 & -.189 & .850 & -.056 & .046 & -.228 & -.014 & -.013 & .609 & 1.641 \\
\hline
\end{tabular}

\subsection{Uji t}

Uji statistik $t$ pada dasarnya menunjukkan seberapa jauh pengaruh satu variabel penjelas/independen secara individual dalam menerangkan variasi variabel dependen. Hipotesis nol (H0) yang hendak diuji adalah apakah suatu parameter (bi) sama dengan nol.
Dari tabel 4.4 di atas menunjukkan $0,000<0,05$, hasil tersebut menunjukkan bahwa $\mathrm{CR}$ signifikan terhadap ROA. Hasil lain juga terlihat dari $t_{\text {hitung }}$ sebesar 3,797 > dari tabel yaitu sebesar 1,974. $t_{\text {tabel }}$ di dapat dengan rumus $(\alpha / 2 ; n-k-1)$ yaitu 0,$025 ; 174$ dan hasil tabel t menunjukkan 1,974. Hal ini menunjukkan menerima hipotesis alternatif yang menyatakan 
bahwa suatu variabel independen secara individual mempengaruhi variabel independen.

Pengujian terhadap TATO juga dapat dilihat dari $0,000<$ dari 0,05 , hal ini menunjukkan bahwa TATO signifikan terhadap ROA. Sementara itu thitung sebesar 3,941 > dari tabel 1,974 hal ini menunjukkan menerima hipotesis alternatif TATO.

Selanjutnya pengujian terhadap CT juga dapat dilihat dari $0,456>$ dari 0,05 , hal ini menunjukkan bahwa CT tidak signifikan terhadap ROA. Sementara itu thitung sebesar $-0,747<$ dari tabel 1,974 hal ini menunjukkan menolak hipotesis alternatif CT.

Dan untuk pengujian terhadap DER menunjukkan 0,850>0,05, hasil ini menunjukkan DERtidak signifikan terhadap ROA. Dan juga hal ini menunjukkan menolak hipotesis alternatif dapat dilihat bahwa thitung sebesar $-0,189<$ dari tabel 1,974 .

\subsection{Uji f}

Uji f digunakan untuk menunjukkan apakah semua variabel independen yang dimasukkan dalam model mempunyai pengaruh secara bersama-sama terhadap variabel dependen.

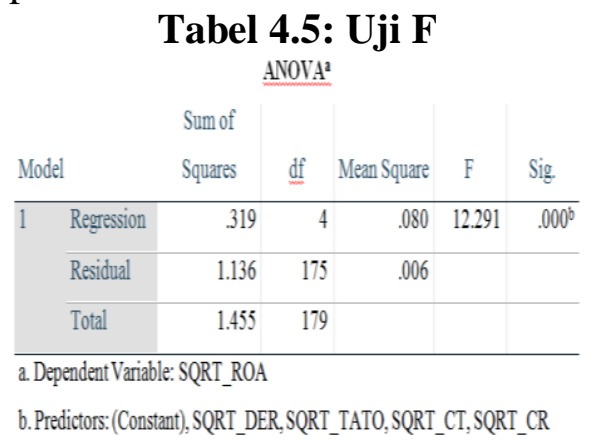

Dari hasil pengujian statistik pada tabel 3.5 dapat dilihat bahwa nilai signifikan nya 0,000 dan lebih kecil dari 0,05 , dan hasil dari F Fitung menunjukkan nilainya sebesar 12,291 yang lebih besar dari $\mathrm{F}_{\text {tabel }}$ sebesar 2,42. $\mathrm{F}_{\text {tabel }}$ di dapat dari hasil perhitungan $\mathrm{F}(\mathrm{k}$ ; $\mathrm{n}-\mathrm{k})=\mathrm{F}(4 ; 176)$ dan setelah dilihat dari $\mathrm{F}$ tabel menunjukkan bahwa hasilnya adalah 2,42. Dari hasil pengujian statistik tersebut variabel independen CR (X1), TATO (X2), CT (X3) dan DER (X4) berpengaruh terhadap variabel dependen ROA (Y).

\section{Pembahasan Hasil Penelitian}

\subsection{Pengaruh Current Ratio} Terhadap Return On Asset

Dari hasil pengujian secara parsial, dapat dilihat hasil pengujian statistik melalui SPSS menunjukkan bahwa pengujian terhadap TATO dilihat dari nilai Sig pada tabel Coefficients yakni $0,000<0,05$, hasil tersebut menunjukkan bahwa $\mathrm{CR}$ signifikan terhadap ROA. Hasil lain juga terlihat dari thitung sebesar 3,797 > dari tabel yaitu sebesar 1,974. tabel di dapat dengan rumus $(\alpha / 2 ; \mathrm{n}-\mathrm{k}-1)$ yaitu 0,$025 ; 174$ dan hasil tabel t menunjukkan 1,974. Hal ini menunjukkan menerima hipotesis alternatif yang menyatakan bahwa suatu variabel independen secara individual mempengaruhi variabel independen.

\subsection{Pengaruh Total Asset Turnover Terhadap Return On Asset \\ Dari hasil pengujian secara parsial, dapat dilihat hasil pengujian statistik melalui SPSS menunjukkan bahwa pengujian terhadap TATO dilihat dari}


nilai Sig pada tabel Coefficients yakni $0,000<$ dari 0,05 , hal ini menunjukkan bahwa TATO signifikan terhadap ROA. Sementara itu $t_{\text {hitung }}$ sebesar 3,941 $>$ dari $t_{\text {tabel }}$ 1,974 hal ini menunjukkan menerima hipotesis alternatif TATO.

\subsection{Pengaruh Cash Turnover} Terhadap Return On Asset

Dari hasil pengujian secara parsial, dapat dilihat hasil pengujian statistik melalui SPSS menunjukkan bahwa pengujian terhadap CT dilihat dari nilai Sig pada tabel Coefficients yakni 0,456 $>$ dari 0,05, hal ini menunjukkan bahwa CT tidak signifikan terhadap ROA. Sementara itu $t_{\text {hitung }}$ sebesar $-0,747<$ dari $t_{\text {tabel }} 1,974$ hal ini menunjukkan menolak hipotesis alternatif CT.

\subsection{Pengaruh Debt to Equity Ratio Terhadap Return On Asset}

Dari hasil pengujian secara parsial, dapat dilihat hasil pengujian statistik melalui SPSS menunjukkan bahwa pengujian terhadap DER menunjukkan nilai Sig pada tabel Coefficients yakni $0,850>0,05$, hasil ini menunjukkan DERtidak signifikan terhadap ROA. Dan juga hal ini menunjukkan menolak hipotesis alternatif dapat dilihat bahwa $t_{\text {hitung }}$ sebesar $-0,189<$ dari $t_{\text {tabel }} 1,974$.

\section{Kesimpulan dan Saran \\ 6.1. Kesimpulan}

Dari hasil penelitian ini diperoleh kesimpulan sebagai berikut:

1. Likuiditas (Current Ratio) secara parsial berpengaruh positif dan signifikan terhadap kinerja keuangan (Return On Assets) pada perusahaan manufaktur yang terdaftar di Bursa Efek Indonesia, sehingga hipotesis pertama (H1) pada penelitian ini diterima.

2. Manajemen Aset (Total Assets Turnover) secara parsial berpengaruh positif dan signifikan terhadap kinerja keuangan (Return On Assets) pada perusahaan manufaktur yang terdaftar di Bursa Efek Indonesia, sehingga hipotesis kedua (H2) pada penelitian ini diterima.

3. Perputaran Kas (Cash Turnover) secara parsial berpengaruh negatif dan tidak signifikan terhadap kinerja keuangan (Return On Assets) pada perusahaan manufaktur yang terdaftar di Bursa Efek Indonesia, sehingga hipotesis ketiga (H3) pada penelitian ini ditolak.

4. Struktur Modal (Debt to Equity Ratio) secara parsial berpengaruh negatif dan tidak signifikan terhadap kinerja keuangan (Return On Assets) pada perusahaan manufaktur yang terdaftar di Bursa Efek Indonesia, sehingga hipotesis keempat (H4) pada penelitian ini ditolak.

5. Current Ratio, Total Asset Turnover, Cash Turnover dan Debt to Equtiy Ratio secara simultan berpengaruh signifikan terhadap kinerja keuangan (Return On Assets) pada perusahaan manufaktur yang terdaftar di Bursa Efek Indonesia, sehingga hipotesis kelima (H5) pada penelitian ini diterima.

\section{Saran}


Saran yang dikemukakan peneliti berkaitan dengan hasil penelitian adalah:

1. Bagi perusahaan manufaktur agar manajemen memperhatikan Current Ratio dan Total Assets Turnover karena variabel ini dapat mempengaruhi kinerja keuangan (Return On Assets).

2. Bagi Universitas Prima Indonesia, disarankan agar hasil penelitian dapat dipergunakan untuk kepentingan penelitian selanjutnya.

3. Bagi peneliti selanjutnya, disarankan untuk menambah variabel penelitian misalnya laba bersih atau ukuran perusahaan karena hasil koefisien determinasi menunjukkan $78,1 \%$ dari variasi variabel dependen (ROA) yang dapat dijelaskan oleh variabel di luar penelitian.

\section{References}

Brigham, E. F., \& Houston, J. F. (2010). Dasardasar Manajemen Keuangan. Jakarta: Salemba Empat.

Fahmi, I. (2017). Analisis Kinerja Keuangan. Bandung: Alfabeta.

Ghozali, I. (2013). Aplikasi Analisis Multivariete Dengan Program IBM SPSS 23, Edisi 8. Semarang: Badan Penerbit Universitas Diponegoro.

Hery. (2015). Analisis Laporan Keuangan. Yogyakarta: CAPS (Center for Academic Publishing Service).

Hery. (2017). Analisis Laporan Keuangan. Jakarta: PT. Grasindo.

Lestari, H. S., \& Dewi, R. (2016). Pengaruh Financial Leverage Terhadap Kinerja
Keuangan Pada Perusahaan Manufaktur Yang Terdaftar Di Bursa Efek Indonesia. Jurnal Manajemen Bisnis - Kompetensi, 57-68.

Nurafika, R. A., \& Almadany, K. (2018). Perputaran Kas, Perputaran Piutang, Perputaran Persediaan Terhadap Profitabilitas Pada Perusahaan Semen. Jurnal Akuntansi dan Bisnis, 98-101.

Nuriyani, \& Zannati, R. (2017). Pengaruh Perputaran Kas Dan Perputaran Piutang Terhadap Profitabilitas Perusahaan Sub-Sektor Food And Beverages Tahun 2012-2016. Jurnal Riset Manajemen dan Bisnis (JRMB) Fakultas Ekonomi Universitas Islam Attahiriyah, 422-432.

Sanusi, A. (2011). Metodologi Penelitian Bisnis. Jakarta: Salemba Empat.

Subramanyam, K. R., \& Wild, J. J. (2014). Analisis Laporan Keuangan. Jakarta: Salemba Empat.

Sugiyono. (2011). Metode Penelitian Pendidikan (Pendekatan Kuantitatif, Kualitatif, dan R\&D). Bandung: Alfabeta.

Sujarweni, V. W. (2014). Metodologi Penelitian. Yogyakarta: PT. Pustaka Baru Press.

Widiasmoro, R. (2017). Pengaruh Perputaran Kas, Perputaran Piutang, Dan Perputaran Persediaan Terhadap Profitabilitas / ROA Pada Perusahaan Manufaktur Yang Terdaftar Di Bursa Efek Indonesia Tahun 2011-2014. Jurnal Penelitian dan Kajian Ilmiah Fakultas Ekonomi Universitas Surakarta, 53-62. 